\title{
Economic Effects of Covid-19 on Tourism Sector in Pakistan
}

\author{
Dr. Asma Akmal \\ Associate Professor, University of Home Economics, Lahore \\ Asmaakmal4@gmail.com \\ Bisma Laeeque \\ Lecturer, The University of Faisalabad, Faisalabad \\ Corresponding Author email:bislaeeque@gmail.com \\ Bakhtawar Mehar \\ Teaching Assistant, University of Home Economics, Lahore \\ kbakhtawar87@gmail.com
}

\begin{abstract}
This research is done to ascertain the economic condition of the people of Pakistan during COVID-19 and the condition of tourism in the country. Despite of fact that travel bans were made along with school closure, however these hurdles did not affected tourism in Pakistan. The company's balance sheet depicts more profit in comparison to previous years but that it is because of high fare and arrangement charges. Not due to increase in number of tourists. Purposive sampling strategy was used and the data was collected from pirvate travelling companies working in Pakistan. It is depicted by the results that the overall profit secured by the companies increased during corona (Mean profit before corona $=89666$; Mean profit during corona $=102915)$. Furthermore the hypothesis was accepted that covid-19 positively effected tourism industry of Pakistan [ $p<.005 ; t=1.51(d f=23) S D=43005.98]$.
\end{abstract}

Keywords: COVID-19, Pandemic, Tourism, Economy

\section{Introduction}

In an already unequal world, Covid-19 Pandemic proved to be a catalyst that furthered the existing breach between developed and developing nations. The world has experienced three deadly outbreaks of coronaviruses in less than two-decade. Recently emerged Covid-19 posed an international concern for global economies. (Ahmad T, Haroon, Baig M, Hui J., 2020). Covid-19 is known as a black swan event and is also connected to the economic recession of World War II (Resilient leadership responding to COVID-19, 2020), it damagesthe global health system and every aspect of human life is on a downward slide. On January 30, 2020, World Health Organization (WHO) declared it a global emergency. To "flatten the curve" certain restrictions were enforced i.e. travel restrictions, quarantine duration, and border were shutdowns in developed countries. (Sohrabi C., 2020 Apr)According to experts, the Covid-19 economic impact could be worse than of Great Depression. Global GDP fell 3\% in 2020 according to International Monetary Fund.World Trade Organization has warned that the volume of world trade could shrink by up to $32 \%$ while the International Labor Organization has indicated that 195 million jobs globally could be lost.(Pasha). (Binti Hamzah et al., 2020) corona tracker research group emphasizedthe usefulness of tracker to indicate day-by-day corona situation. In the discussion, they described the political and economic impact of COVID- 19. The government's role is very 
significant during this pandemic regarding information sharing, cost control, and public trust. The travel bans, border closing, and trade control were indispensable measures to control the spread of disease but its economic impact is extremelyambiguous.

To understand the turmoil'sinfluence on the economy, this article comprises of summaries of the available literature for a better understanding of the economic situation. In addition to that to determine the effect of COVID on tourism, data from two tourism companies have been compared to get a true depiction of the prevailing scenario. Following hypothesis was formulated for the current study:

\section{$\mathrm{H}_{1}$ : COVID-19 positively affected tourism industry of Pakistan}

\subsection{Low Economic Growth for 2020}

(Meissner, 2020)described that lockdowns not only affect the economy of areas which have been shut down but also of the areas which are not under lockdown. Control strategies were adopted by almost all countries of the world to regulate the spread of disease. These interventions reduce people's willingness to work, perturb their consumption patterns, lowered consumption, and inculcatedstrain to the financial system. NPIs slowed down the Health vs. Wealth? Public Health Policies and the Economy during Covid-19 disease are spread. There is evidence of spillover and little evidence of declined economic activity.

(Bonaccorsi et al., 2020) shed light onthe impact of lockdown on the economic conditions of the communities. The lockdown in Italy initially affected communities of higher fiscal doings secondly municipalities where variation is higher and thirdly lower income group areas. This paper proposes an unprecedented fiscal trial; central and local fiscal revenues will be depressing so additional resources are needed to toleratethe retrieval of the weaker segment of the population.

\subsection{Supply and Demand Shocks}

(Gupta et al., 2020) in his report indicated that lockdown and restrictions in one area can disrupt supply chain of the entire world market. Since the world that now is a global community where any event in one country affects all other countries also. China is the hub of production ranging from pharmaceuticals to automobiles. The supply of raw material for pharmaceuticals was also affected. These diseases decreased gross domestic production from $2.9 \%$ to $2.4 \%$ across the globe. The longer the virus binges the more economic performance will be impacted.

(Barua, 2020) described in his research that COVID-19 affected all (poor \& rich) the economies of the world. This investigationdirected macroeconomic shockwave areas, like demand, supply, supply chain, price level, etc. In an in-depth analysis, he highlighted the topographiesthat government and international institutions need to mitigate economic shocks. All Governments should devise and design economic dogmas as timely as possible.

(Janosik, 2005) in one of his series of publications pointed out, corporate firms' traits concerning stock price reaction to COVID-19. They composed data from 6000 firms across 56 economies during the first quarter of 2020. Research indicators are pre-2020, firm's financial condition, international supply chain and customer location, CSR activities, and corporate governance system. The findings indicated that the firms which had strong pre-2020 financial conditions experience superior stock price COVID -19 reactions. The firms which have international supply chain and customer location experienced plungedthe stock price. The firms with strong SCR policies and activities have superior stock price performance. The firms with less rooted executives performed better in response to COVID-19. The uniqueness of the firm is strongly 
associated with the stock price; the firms owned by circumvented funds perform worse than firms owned by non-financial corporations.

(del Rio-Chanona et al., 2020) This paper estimated supply-demand shock during the lockdown. They developed ancatalog of labor who can work from home and those who couldn't and essential vs non-essential industries. The idea is to compare supply and demand shock. The findings indicated that the transport industry had demand-side shock and manufacturing, mining, and service industries had a supply-side shock. The high wages occupations are more resistant to these shocks as compare to low wages. The magnitude of the shock is colossal in the US because a quarter of the economy is at homes not working.

(Wyplosz, 2020) in his e-book described that COVID-19 hits the world pathologically as well as financially. The US, Japan, Britain France, and Italy are the ten most affected countries that sums up to for $60 \%$ of world supply and demand (GDP), $65 \%$ world manufacturing, and $40 \%$ of world manufacturing exports. These economies are also ashare of the world supply chain. This pandemic affects the manufacturing sector in three ways firstly supply disruption hindered production secondly supply chain contagions magnify the direct supply shocks and thirdly demand disruptions due to recessions and wait $\&$ see purchase delays by consumers and firms.

(Inoue \& Todo, 2020) reported that demand and supply chain affected due to lockdown in Tokyo. The one-month lockdown in Tokyo will decreasethe production of another region to 27 trillion yen. The annual GDP will be lessened to 5.3\%. The shutdown in Tokyo will reduce production by $86 \%$ in a month.

(Baker et al., 2020) commented on respondents' spending patterns during the lockdown and social distancing in the US. The analysis revealed that household spending increases during early weeks of lockdown especially groceries but then there was a severe decline. Demographic characteristics like age and family size inciteda larger level of heterogeneity in spending patterns instead of income. The researcher commented that social distancing, loss of a job, and disease outbreak intensity can be the causeforthe decline in spending.

(Ashraf, 2020) reported that social distancing measures have a direct negative impact on the stock market of these countries. They collected data from 77 countries on 22 April. The lockdown had auninterrupted negative effect on the stock market and economic activity of the country, But Government income support packages had a positive impact on countries' economies.

\subsection{Unemployment}

(Coibion et al., 2020) in a customized survey of 10,000 respondents described the economic impact on households. The 50\% respondents reported income (5.293 \$) and wealth losses of (33.482 \$). Consumer spending reduced to $31 \%$ on travel and clothing. The researcher's predicteda higher joblessness rate due to lockdown in the upcoming 13 to 14 months. They are guessinga low inflation rate, higher certainty, and lower mortgage rate for the 10 years to come.

(Béland et al., 2020)inspectthe short-term impact of COVID-19 on employment and wages in the United States. They find out that this pandemic increases unemployment. They investigated labor market employment and wages at the national and state level. Their results showed a high rate of unemployment among labor but there is no change in earnings. It affects the labor market of men, young workers, Hispanics, and less-educated workers and created labor disparities. They estimated that occupations in immediacy to others are more affected as compare to occupations able to work remotely are less affected. The long-term consequences of this disease as compared to AIDS in Africa, the Spanish Flu, and Black Death in Britain are still unknown.

(Barrero et al., 2020) a survey of Business ambiguity reported that 28 million people claimed 
unemployment in the US in 2020. This survey built novel, forward-looking reallocation measures for jobs and transactions. They found out three new chartering for every ten layoffs like WalMart, Amazon, etc. but $42 \%$ of layoffs will be long-lasting job loss.

(Fernandes, 2020) in his report discussed the economic impact of COVID -19 on the world economy. He describes that amidst all problems IMF has developed some new estimates for growth in 2020 (Feb 2020). In its revised approximations, the IMF expects China to slow down by $0.4 \%$ points, as well as a slowdown of global growth by $0.1 \%$ points. The OECD also revised their estimates in early March. It forecasted global economic growth subsiding to $2.4 \%$ for the unabridged year, associated to $2.9 \%$ in 2019. The scholarassumed that the growth rate will reduce much more than this approximation in the coming months. The world will experience a recession which will be different from World War II. The economy is experiencing demand \& supply shock, countries with more service-oriented economies will be more affected. This statement outlines some possible economic circumstances and policy repercussions. Number one disbursements on health, illness, and death cannot be estimated accurately this time as it was in previous diseases like SARS, HIV/AIDS, etc yet at the same time, he reported that mortality and economic impact are not associated. According to him all service-providing professions like hotels, airlines, barbers; etc will be effectedby lockdown and leads to redundancy.

\subsection{Poverty}

(Sumner et al., 2020) in a research estimated poverty impact of COVID-19 in developing countries. They estimated that if there will be 5\% shrinkage in per capita income of the family, the increase in poor people will be more than 80 million for the US $\$ 1.9 /$ day poverty line, more than 130 million for US \$ 3.2/ day standard and 124 million for a higher line of US \$ 5.5/day. If per capita income will decrease to $10 \%$ the increase in poor people will be 180,280 , and 250 million for all above US standards respectively. In case of a $20 \%$ decrease, this increase will be 420, 580, and 540 million. This condition is a challenge for the UN Sustainable development goal of ending poverty in2030. All these poor people are from SSA, South Asia, East Asia, and the Pacific.

(Tarigan, 2020) in NBER working paper series sheds light on how COVID-19 affected small businesses. In a survey of 5,800 small companies, they found out that $43 \%$ of businesses were temporarily closed and $40 \%$ reduction in employee count. The companies with $\$ 10,000$ monthly expenses were financially fragile. The businessmen are uncertain about COVID disruptions. Many companies planned to seek funding from government agencies.

(Kabir et al., 2020) highlighted an important issue of forcibly displaced people. They pointed out that 7.8 million people will forcibly displace as a result of this pandemic, 4.3 million inside, 25.9 million refugees, and 3.5 million asylum seekers. UNHCR funded all the refugee camps with the donation of the top 15 economies of the world. These economies are badly affected by COVID 19 , which is why they will not be able to donate to this fund. Reduction in funds of UNHCR will lead to poor living conditions in refugee camps.

(Bhuiyan et al., 2020) described in their research 7-8 suicide cases in Bangladesh because of economics and psychological stress of COVID-19. Bangladesh was already facing all the economic problems of developing countries like corruption, low per capita income $(0.23 \$$ in April 2020), people living below the poverty line, etc. The lockdown increases their economic problem; unemployment and inflation. The necessities of life became very lavish due to a shortage of supply and cause frustration for underprivileged families.

(Nicola et al., 2020) in literature review summarize that COVID-19 will increase economic crises 
and recession all over the world due to social distancing, self-isolation, travel restrictions, and job losses. At the same time, the need for medical and food supplies is staggering. (Ahmad et al., 2020) reported that China's economic growth fallen to $5.6 \%$ this year there is a dire requirement for regional and international cooperation to encompass hands to prevent further dispersal of COVID-19.

(Acs \& Karpman, 2020) a survey reported that unemployment in adults increases during this pandemic. $48.3 \%$ of the low-income group experienced job losses as paralleled to $39.5 \%$ of adults from the high-income group. 55.0\% of Hispanic adults experienced unemployment as compare to white $40.0 \%$ non-Hispanic adults.

\subsection{The Burden on Poor Governments}

(Walker et al., 2020)The health care organizationneeds strategic planning to handle the situation. These governments are not only necessitated to expend more on health facilities but at the same time on the economic wellbeing of their people also. Conglomerated data of lower-income and middle-income countries. They gathered demography, contact pattern, disease severity, and health care capacity of these countries. In low-income and middle-income countries health systems lack facilities (ICU, Ventilators, testing Capacity, etc.) to handle the situation well.

According to (Fernandes, 2020) the COVID-19 affect the global stock market gravely since ( The oil price war between Saudi Arabia \&Russia) 1987. This is a new type of crisis, the GDP of every country took a hit ranging from 3-5\% and it can fall to 10\%. Each supplementary month of lockdown costs 2\%-2.5\% of global GDP. The economic costs of recession are similarlydistributed; younger \& lesser-educated employees are losing their jobs. Countries that are highly dependent on tourism are more affected in this situation.

(McKibbin \& Fernando, 2020) presented in their paper short term and long term strategicalconsequence to reduce the economic cost of the ailment. In the short term, central banks and treasuries of each nation should cut down the interest rates to keep the economies serviceable. This is a multi-faceted calamity that will necessitate monetary, fiscal, and health policy rejoinder by the government. The long-term responses are more important and need to address globally. Governments especially in poor countries need to invest in their health care systems to circumvent such diseases in the future. All countries need to participate in the improvement of the health sector of the world. Global collaboration in the public sector is highly commended in this study.

(Ataguba, 2020) in a paper discussed health facilities of African countries. There are socioeconomic inequalities in health in these states so administrations should devote more on this sector to control the disease. It's a warlike situation; countriesthat spend more on security in war this periodrequiredisbursements on community health.

(Buheji et al., 2020)The world should target to get rid of the negative impact of COVID-19 by facilitating poor communities. This pandemic also investigates the community system of every state. Governments should devise such health care prototypes which can cater to poor segment of the community. COVID-19 affects the unfortunateand fragile economies in harsher ways; it reduces agricultural activities tourism trade, and industry. In rich countries, it has long-term effects such asrecession.

(Wright et al., 2020) commented that the compliance of social distancing and shelter in place regulation varies across the US. The reason bind this variation is an economic endowment. Lower-income areas comply less than counties with stronger economic benefactions.

\subsection{Impact on Pakistan}


(Chohan, 2020)said in his paper that, The virus has affected both the production and distribution of goods across the country. In FY20 downwards trend will be observed however the damage could be reversed by rigorously working so that the effects waver off in FY21. The country suffers from resource constraints and is incapable of launching programs like Universal Basic Income (UBI). Irrespective of the constraints during COVID19 the government tried to provide relief of a modest size called the Ehsas program.(Khan, Ali, \& Aftab, 2020).Poverty scare and product layoffs have resulted due to lessened demand of goods in certain cases of products while impulsive buying is also visible in case of stocking medicine, toiletries, and groceries. (Nicola et al., 2020) Another study reported that the stock market was only affected by the performance of the index and was not affected by the number of per diem positive cases and number of casualties. (Hoque, Shikha, Hasanat, Arif, \& Hamid, 2020)The intensification of the Coronavirus is being thought to cause a long-term influence on the tourism industry of the country.

\section{Method}

With the purpose of analyzing the impact of COVID-19 on tourism in Pakistan quantitative method was used to analyze the data procured from two private tourism companies in Pakistan from March to November 2020. Client revenue was calculated during first phase of Covid-19 from March till August 2020, the first wave period of epidemic and then from September 2020 to December 2020, the second wave period of disease in Pakistan. Purposive sampling strategy was used. The study applies a statistical method in which items were analyzed to gather a comprehensive idea regarding tourism in Pakistan. A qualitative analysis was also done by studyingexisting literature on the subject, summaries of which are provided in introduction. The following sources were used to retrieve the data regarding tourism in different countries:

- Previous studies

- Reports of the World Tourism Organization

- Reports of the World Travel and Tourism Council

\section{Results}

Table 1: PAIRED SAMPLES STATISTICS

\begin{tabular}{|lrrrr|}
\hline & Mean & N & Std. Deviation & Std. Error Mean \\
\hline Overall_profit_in_corona & 102925.0000 & 24 & 94273.60735 & 19243.51952 \\
\hline Overall_profit_pre_corona & 89666.6667 & 24 & 74918.45664 & 15292.66592 \\
\hline
\end{tabular}

Table 2: PAIRED SAMPLES TEST

\begin{tabular}{|c|c|c|c|c|c|c|c|c|}
\hline & \multicolumn{5}{|c|}{ Paired Differences } & \multirow[t]{3}{*}{$\mathbf{t}$} & \multirow{3}{*}{$\begin{array}{l}d \\
f\end{array}$} & \multirow{3}{*}{$\begin{array}{l}\text { Sig. } \\
(2- \\
\text { taile } \\
\text { d) }\end{array}$} \\
\hline & \multirow[t]{2}{*}{ Mean } & \multirow[t]{2}{*}{$\begin{array}{l}\text { Std. } \\
\text { Deviat } \\
\text { ion }\end{array}$} & \multirow{2}{*}{$\begin{array}{c}\text { Std. } \\
\text { Erro } \\
\text { r } \\
\text { Mea } \\
\text { n }\end{array}$} & \multicolumn{2}{|c|}{$\begin{array}{c}95 \% \\
\text { Confidence } \\
\text { Interval of the } \\
\text { Difference }\end{array}$} & & & \\
\hline & & & & $\begin{array}{c}\text { Lowe } \\
\quad \mathbf{r}\end{array}$ & Upper & & & \\
\hline Overall_profit_in_c & 13258 & 43005 . & 8778. & 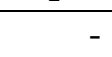 & 31418 & 1.5 & 2 & .000 \\
\hline $\begin{array}{l}\text { orona - } \\
\text { Overall_profit_pre_ } \\
\text { corona }\end{array}$ & .33 & 98 & 55 & $\begin{array}{r}4901 . \\
50\end{array}$ & .16 & 10 & 3 & \\
\hline
\end{tabular}


The table above indicates hypothesis tested, the test was conducted at a confidence level of $95 \%$ and the results were significant, meaning thatcovid-19 positively impacted tourism industry of Pakistan and the overall profit made by travelling companies before and during corona pandemic is different $[p<.005 ; \mathrm{t}=1.51(\mathrm{df}=23) \mathrm{SD}=43005.98]$. It was revealed by mean comparison in paired sample $t$-test that the travelling companies secured more profit during the pandemic $(M=19243.52)$ as compared to before corona pandemic $(\mathrm{M}=1592.67)$

Table 3: CORRELATIONS

\begin{tabular}{|llrr|}
\hline & & Overall_profit_in_corona & no._tourist \\
\hline Overall_profit_in_corona & Pearson Correlation & 1 & .024 \\
& Sig. (2-tailed) & & .913 \\
& $\mathrm{~N}$ & 24 & 24 \\
\hline no._tourist & Pearson Correlation & .024 & 1 \\
& Sig. (2-tailed) & .913 & \\
& $\mathrm{~N}$ & 24 & 29 \\
\hline
\end{tabular}

The above table presents correlation between overall profit made by the travelling companies in Pakistan and the number of tourists who opted to travel during the pandemic. A strong positive, direct correlation was found between the numbers of tourists who opted to travel during corona in Pakistan with the overall profit made by the travelling companies during the period. The value of Pearson Correlation can be the seen in the table above i.e.(.913) which is very close to 1, indicating the existence of a direct strong positive relationship between number of tourists who choose to travel in corona and the profit made by the travelling companies during the pandemic.

\section{Discussion}

Tourism is considered a luxury in developing countries. In COVID-19 people's economic conditions become worst and unlike all industry tourism did not suffered from the impediment as greatly. The results of this study exhibited that during corona times instead $f$ dwindling the tourism sector rather flourishes in the country and secured more profit that usual routine. After correlation testing it was also established that there was a strong direct positive relationship between profits made by tourism sector and pandemic, indicating that a lot of people choose to travel as they were too frustrated by lock downs, restrictions and social distancing.

\section{Conclusion}

The outburst of COVID-19, termed as Black Swan Events, causes substantial harm worldwide due to its fatality. Because of the bans, curfews, stay-home and work-from-home schemes, and quarantines, the COVID-19 pandemic has spread worldwide by generating shocks in almost all industries. As a result of the health and economic crisis with the COVID-19 pandemic, the tourism industry is greatly affected. According to the World Travel and Tourism Council, the Direct Contribution of Travel and Tourism to Pakistan's GDP in 2016 was US\$ 7.6 billion, constituting 2.7 percent of the total GDP and they predict by the year 2025 tourism will contribute Rs.1 trillion to Pakistan's economy. Travel and Tourism Total Contribution to GDP to Pakistan in 2016 was US\$ 19.4 billion. The direct contribution to employment by Travel and tourism in Pakistan was 1,337,500 jobs in 2016. The total contribution of Travel and Tourism to employment in Pakistan was 3,550,500 jobs in 2016. Investments in Travel and Tourism in Pakistan in 2016 were US\$ 3.6 billion whereas the Visitor Exports made in 2016 by Pakistan 
were US\$ 0.9 billion. However, these estimates and calculations regarding the tourism industry in Pakistan were pre-pandemic.

During the pandemic, according to the results of this study it is exhibited that in Pakistan tourism has increased during the pandemic. There is a positive impact on the economy that has created a considerable profit in pandemic days. Economic development agencies and government authorities should work for destination management and planning so with the ongoing rapid increase in the number of tourists both domestic and international can explore Pakistan in a safe environment in COVID scenario. Furthermore actions should be taken to safeguard and preserve beauty of Pakistani landscape so that the tourist attraction sites are conserved as well.The tourism industry is the world biggest industry contributing most of the GDP of any economy and it is flourishing these days in Pakistan. However these findings are not supported by the work of (Hoque, Shikha, Hasanat, Arif, \& Hamid, 2020)

This research has exhibited that strategic planning and sound administration are vital in accomplishing sustainable development objectivesespecially in regards to healthcare and disease prevention and control. There is a requirement for those in charge of managing destinations to start thinking in a harmonized way, not only on the ordinary concerns of tourism but also on the health related aspects so that people keep travelling during such challenging times and Pakistani economy keeps profiting from tourism in these testing times of COVID-19

\section{References}

Acs, G., \& Karpman, M. (2020). Employment, Income, and Unemployment Insurance during the COVID-19 Pandemic. 1-11.

Ahmad, T., Haroon, Baig, M., \& Hui, J. (2020). Coronavirus disease 2019 (Covid-19) pandemic and economic impact. In Pakistan Journal of Medical Sciences (Vol. 36, Issues COVID19S4, pp. S73-S78). https://doi.org/10.12669/pjms.36.COVID19-S4.2638

Ashraf, B. N. (2020). The economic impact of government interventions during the COVID-19 pandemic: International evidence from financial markets. In Journal of Behavioral and Experimental Finance (Vol. 27). https://doi.org/10.1016/j.jbef.2020.100371

Ataguba, J. E. (2020). COVID-19 Pandemic, a War to be Won: Understanding its Economic Implications for Africa. Applied Health Economics and Health Policy, 18(3), 325-328. https://doi.org/10.1007/s40258-020-00580-x

Baker, S. R., Farrokhnia, R. A., Meyer, S., Pagel, M., \& Yannelis, C. (2020). How Does Household Spending Respond to an Epidemic? Consumption During the 2020 COVID-19 Pandemic. SSRN Electronic Journal, March. https://doi.org/10.2139/ssrn.3565521

Barrero, J. M., Bloom, N., \& Davis, S. J. (2020). COVID-19 Is Also a Reallocation Shock. SSRN Electronic Journal, May. https://doi.org/10.2139/ssrn.3592953

Barua, S. (2020). Munich Personal RePEc Archive Understanding Coronanomics: The economic implications of the coronavirus (COVID-19) pandemic Understanding Coronanomics: The economic implications of the coronavirus (COVID-19) pandemic. SSRN Electronic Journal Https://Doi Org/10/Ggq92n., 99693, 1-45.

Béland, L.-P., Brodeur, A., \& Wright, T. (2020). The short-term economic consequences of COVID-19: Exposure to disease, remote work, and government response. IZA Discussion Paper, 13159, 90. www.iza.org

Bhuiyan, A. K. M. I., Sakib, N., Pakpour, A. H., Griffiths, M. D., \& Mamun, M. A. (2020). COVID-19-Related Suicides in Bangladesh Due to Lockdown and Economic Factors: Case Study Evidence from Media Reports. International Journal of Mental Health and Addiction. 
https://doi.org/10.1007/s11469-020-00307-y

Binti Hamzah, F. A., Lau, C. H., Nazri, H., Ligot, D. C., Lee, G., Tan, C. L., \& et al. (2020). CoronaTracker: Worldwide Covid-19 outbreak data analysis and prediction. Bulletin of the World Health Organization, March, Submitted.

Bonaccorsi, G., Pierri, F., Cinelli, M., Flori, A., Galeazzi, A., Porcelli, F., Schmidt, A. L., Valensise, C. M., Scala, A., Quattrociocchi, W., \& Pammolli, F. (2020). Economic and social consequences of human mobility restrictions under COVID-19. Proceedings of the National Academy of Sciences of the United States of America, 117(27), 15530-15535. https://doi.org/10.1073/pnas.2007658117

Buheji, M., da Costa Cunha, K., Beka, G., Mavrić, B., Leandro do Carmo de Souza, Y., Souza da Costa Silva, S., Hanafi, M., \& Chetia Yein, T. (2020). The Extent of COVID-19 Pandemic Socio-Economic Impact on Global Poverty. A Global Integrative Multidisciplinary Review. American Journal of Economics, 2020(4), 213-224. https://doi.org/10.5923/j.economics.20201004.02

Chohan, U. W. (2020). Forecasting the Economic Impact of Coronavirus on Developing Countries: Case of Pakistan.

Coibion, O., Gorodnichenko, Y., \& Weber, M. (2020). The Cost of the COVID-19 Crisis : Lockdowns, Macroeco-.

del Rio-Chanona, R. M., Mealy, P., Pichler, A., Lafond, F., \& Farmer, D. (2020). Supply and demand shocks in the COVID-19 pandemic: An industry and occupation perspective. 1-38. http://arxiv.org/abs/2004.06759

Fernandes, N. (2020). Economic effects of coronavirus outbreak ( COVID-19) on the world economy Nuno Fernandes Full Professor of Finance IESE Business School Spain. SSRN Electronic Journal, ISSN 1556-5068, Elsevier BV, 0-29.

Gupta, M., Abdelmaksoud, A., Jafferany, M., Lotti, T., Sadoughifar, R., \& Goldust, M. (2020). COVID-19 and economy. Dermatologic Therapy, March. https://doi.org/10.1111/dth.13329

Hoque, A., Shikha, F. A., Hasanat, M. W., Arif, I., \& Hamid, A. B. A. (2020). The effect of Coronavirus (COVID-19) in the tourism industry in China. Asian Journal of Multidisciplinary Studies, 3(1), 52-58.

Inoue, H., \& Todo, Y. (2020). The Propagation of the Economic Impact through Supply Chains: The Case of a Mega-City Lockdown against the Spread of COVID-19. In SSRN Electronic Journal. https://doi.org/10.2139/ssrn.3564898

Janosik, S. M. (2005). NBER working paper. NASPA Journal, 42(4), 1. https://doi.org/10.1017/CBO9781107415324.004

Kabir, M., Afzal, M. S., Khan, A., \& Ahmed, H. (2020). COVID-19 pandemic and economic cost; impact on forcibly displaced people. In Travel Medicine and Infectious Disease (Vol. 35). https://doi.org/10.1016/j.tmaid.2020.101661

Khan, M. F., Ali, S., \& Aftab, N. (2020). The Economics and World Economy: Impacts on Pakistan. Electronic Research Journal of Social Sciences and Humanities, 2.

McKibbin, W. J., \& Fernando, R. (2020). The Global Macroeconomic Impacts of COVID-19: Seven Scenarios. SSRN Electronic Journal. https://doi.org/10.2139/ssrn.3547729

Meissner, C. M. (2020). Health vs. Wealth? Public Health Policies and the Economy During Covid-19. NBER WORKING PAPER SERIES.

Nicola, M., Alsafi, Z., Sohrabi, C., Kerwan, A., Al-Jabir, A., Iosifidis, C., Agha, M., \& Agha, R. (2020). The socio-economic implications of the coronavirus pandemic (COVID-19): A 
review. In International Journal of Surgery (Vol. 78, pp. 185-193). https://doi.org/10.1016/j.ijsu.2020.04.018

Walker, P. G. T., Whittaker, C., Watson, O. J., Beguelin, M., Winskill, P., Hamlet, A., Djafaara, B. A., Cucunubá, Z., Mesa, D. O., Green, W., Thompson, H., Nayagam, S., Ainslie, K. E. C., Bhatia, S., Bhatt, S., Boonyasiri, A., Boyd, O., Brazeau, N. F., Cattarino, L., ... Ghani, A. C. (2020). The impact of COVID-19 and strategies for mitigation and suppression in low- And middle-income countries. Science, 369(6502), 413-422. https://doi.org/10.1126/science.abc0035

Wright, A. L., Sonin, K., Driscoll, J., \& Wilson, J. (2020). Poverty and Economic Dislocation Reduce Compliance with COVID-19 Shelter-in-Place Protocols. SSRN Electronic Journal. https://doi.org/10.2139/ssrn.3573637

Wyplosz, C. (2020). 14 The good thing about coronavirus, book: Economics in the Time of COVID-19. www.cepr.org

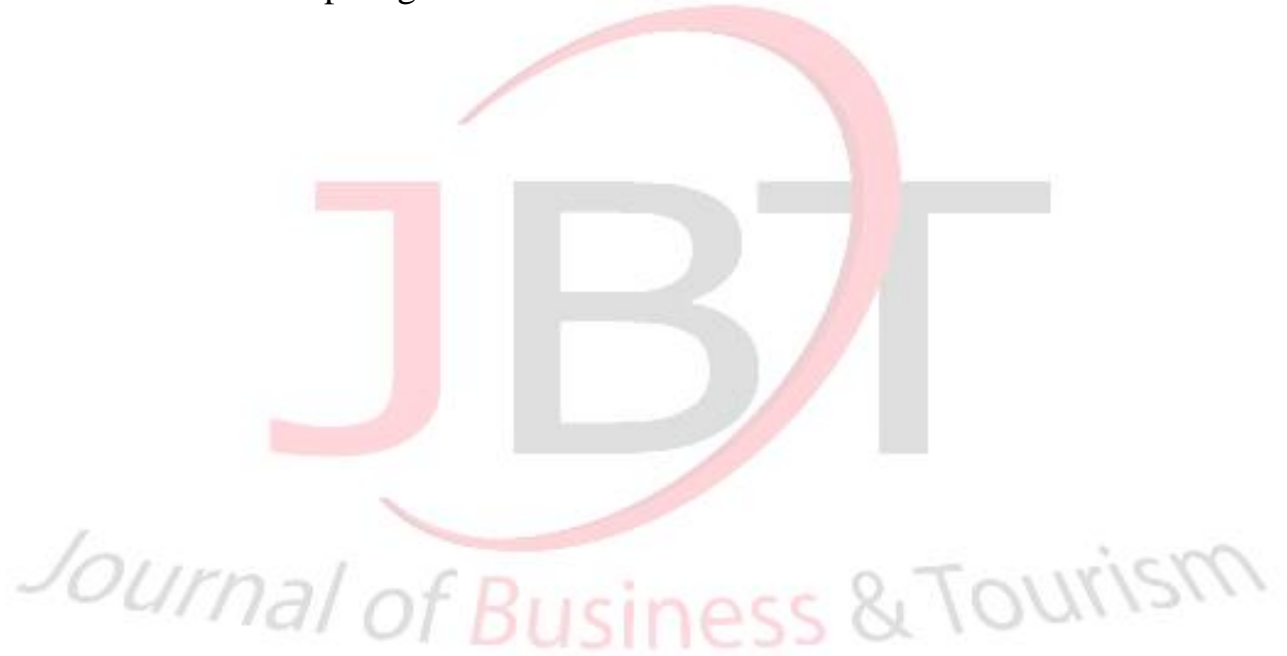

